Marša Meznarič

UDK 374(497.4):81'243

Montessori Inštitut, zavod za pomoč staršem pri razvoju otrok

Slovensko društvo učiteljev angleškega jezika IATEFL Slovenia

meznaric.marsa@gmail.com

\title{
WHICH SECOND LANGUAGE LEARNING THEORIES UNDERLIE LANGUAGE COURSES OFFERED BY SLOVENE PRIVATE LANGUAGE SCHOOLS
}

\section{INTRODUCTION}

In public schools teachers need to follow the nationally accepted syllabus, whereas managers of private language schools, which do not provide courses with nationally acclaimed programs, have the freedom to choose among the various theoretical approaches to second language teaching. The question is whether private schools choose the method(s) on the basis of their professional experience, according to the current guidelines, according to research on second language learning or whether they decide to listen to what their instinct tells them is best.

The task of deciding how to go about teaching must be difficult and complicated for private schools, especially because the proponents of each of the various theories, approaches and methods all guarantee successful learning. They all claim to know how a second language is in fact learned, what personal characteristics of a learner influence the process of acquisition and how, what the most suitable environment for language learning is, and how teachers can best aid students during the process of learning a foreign language.

In the article $\mathrm{I}^{1}$ provide an answer to the question of how managers opt for one method. Interviews were conducted with private language schools' managers and schools' websites were analysed. In the interview I sought answers to the following sets of questions:

- What arguments do private language schools use to support their (seemingly) professional attitudes towards second language learning on their websites? Is the applied theory/method/approach explained on the website, and if they do not apply any particular method do the advertisements then comprise of professionally vague statements?

- Do schools decide to follow one method or one approach to second language teaching or do they decide for an eclectic approach? What are the criteria for choosing either one of the options? Furthermore, do they know what theoretical basis their way of teaching has, and if it has no theoretical grounds, are they aware of that? How often does the process of self-evaluation of the teachers and the company's work take place?

- Are the managers and their employees language teachers? If not, do they employ a language teacher as an assistant or advisor? What professional support do schools offer to their

1 Članek je nastal na podlagi diplomske naloge, ki sem jo napisala pod mentorstvom izr.prof. Janeza Skele na Filozofski fakulteti. 
teacher trainees (regarding the choice of materials, organising seminars, giving advice and professional guidance)?

The article offers a brief theoretical overview of second language learning theories and approaches and only lists the corresponding methods as a preface to the empirical part. The empirical part of the project however is discussed in detail.

\section{CHANGES IN METHODOLOGY OF SECOND LANGUAGE TEACHING AND LEARNING}

Before diving into the sea of methods, an explanation of the term methodology is necessary. After evaluating various definitions, Rodgers (2001: 341) states that "methodology can be understood as a set of principles underlying practice". We can consider methodology as a term for "classroom activities directed at the inducement of language learning" (ibid.). In conclusion Rodgers (ibid.) says that we can refer to methodology as to "a range of pedagogic practices, some of which become specified as prescribed methods".

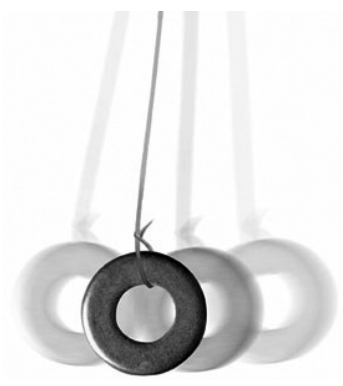

Picture 1: The Pendulum

Having examined the various theories, approaches and methods of second language learning and teaching, we learn that they were in most cases developed in reaction to one another. Celce-Murcia (2001:3) goes as far as to claim that the language teaching and learning research have had "fads and heroes [who] have come and gone in a manner fairly consistent with the kinds of changes that occur in youth culture". Hubbard et al. (1983: 37-38) agree that "because we have lacked solid scientific evidence, the teaching of foreign languages in general has been for a long time the victim of fashion". While the latter authors believe the reason for these swings of the pendulum (a frequent metaphor for the development of language teaching methods) has been the lack of scientific evidence, Celce-Murcia (2001: 3) is of the opinion that the swings have been the consequence of teachers' ignorance. She claims teachers have been unable to appropriately evaluate new methods due to the lack of knowledge of the changes that have occurred in this field of expertise over the course of history from the medieval times onwards.

In his article Is Direct Method in Our Madness?, Guy Cook (2001: 19-20) talks about the negative influences of the frequent shifts in the methods and approaches in the language teaching practice. He subtly implies that it was the lack of knowledge on the teachers' behalf that allowed for various techniques - which 
had proven to be successful once before - to be dismissed, such as translation or drill exercises. Certain methods have been dismissed and others praised interchangeably throughout history.

In the last two or three decades, there has been a tendency of applying the eclectic approach in classrooms i.e. using different teaching techniques. This was considered to be a reaction to teachers following a single method. Rodgers (2001: 348) agrees this has occurred as a consequence of the fact that the methods prescribed were too rigid. He (ibid.) claims that "no account was taken of the variable socio-cultural and individual characteristics of teachers and students, so there was an imposition of conformity in a naturally dynamic process."

Rodgers (ibid.) continues that although the methods could not be adopted in different contexts, because they "left little room for any necessary adaptation", teachers worldwide have somehow picked up and applied many ideas and/or techniques suggested in the chapters describing the practical use of various individual methods.

Rodgers (2001: 349) also argues that with the rise of the need for flexibility, teachers turned their backs on methods and welcomed the notions of approaches and lists of methodological principles, which do not rigidly prescribe the techniques of teaching, but give guidelines as to what the priorities in teaching are.

However, as Hubbard et al. (1983: 37-38) oppose teaching according to one method, they also disagree with teachers adopting various techniques without evaluation and without possessing basic theoretical knowledge. They insist that teachers be acquainted with the turbulences that occurred in the development of language teaching methods and approaches, as this would enable them to critically analyse the techniques they wish to use in class.

\section{THEORETICAL FRAMEWORK}

\subsection{Second Language Learning Theories}

The theories described below are in fact psychological theories of learning and theories of applied linguistics which were used to draw conclusions on how we learn languages.

\subsubsection{Behaviourism}

The theory of imitating and reinforcing language structures to acquire a set of habits for speaking a first language was transferred to theories on second language learning. Learning is viewed as forming habits of correct language with extensive practice. During the process of learning a second language, previously formed habits in the mother tongue might influence the course of the second language development, either positively or negatively. Lightbown and Spada cite Robert Lado's work from 1964 stating that "these habits [in the mother tongue] interfere with those needed for second language speech, and new habits must be formed."

When this influence, termed transfer in contrastive analysis bypothesis $(\mathrm{CAH})$, is beneficial for learners, it is called positive transfer - theoreticians say that transfer 
is helpful in the areas where the two languages are similar. However, it may be the cause of learners' mistakes, and then it is termed negative transfer or interference. The theory on interference was proved to be incomplete, though, by several researchers, who claim that

the influence of the learner's first language is not simply a matter of habits, but a much more subtle and complex process of identifying points of similarity, weighing the evidence in support of some particular feature, even reflecting about whether a certain feature seems 'to belong" in the structure of the target language.

M. Lightbown and Spada (1993)

Hutchinson and Waters (1987: 40) summarized some principles when applying this theory in classrooms:

1. The learner should not translate.

2. The learner should deal with unknown language in the order: hear, speak, read, and write.

3. The learner will be effective in language learning when structures are often repeated and practised.

4. One should correct the learner's mistakes instantly.

The authors observe that the behaviourist theory had a huge impact on second language learning and that we can still witness an enormous amount of drill exercises in many ESL books.

\subsubsection{Mentalism}

Chomsky confronted the behaviourists with a question, namely how a person could deal with all the limitless range of possible situations in speaking a second language by mastering only a limited number of forms learnt by forming habits. In his theory he argues that the human mind is "rule-governed" (Hutchinson A., and Waters A. (1987: 39)); that the linguistic rules we learn are then applied to different situations. He describes learning as a process of acquiring rules and not as a process of forming habits. The theory of cognitive code was constructed on the basis of Chomsky's theory of mentalism.

\subsubsection{Cognitivism}

Lightbown and Spada (1993: 25) argued that this theory was fairly new to ESL research almost 20 years ago when their book was published, and had not yet been placed into the linguistic framework. The theory has been of great importance when it comes to our perception of learning as it moves away from the behaviourist theory.

Cognitive psychologists assert that the learner is not a passive receiver of information, but an active processor of it. Hutchinson and Waters (1987: 43) claim that "[l]earning, then, is a process in which the learner actively tries to make sense of data." They further claim that learning takes place when one has meaningfully interpreted the data. In practice this means that learners must think about what they experience with their senses.

Another aspect of the cognitive approach called reconstructing is explained by Lightbown and Spada (1993: 25). The term is reminiscent of schemata ("a mental 
codification of experience that includes a particular organized way of perceiving cognitively and responding to a complex situation or set of stimuli"), since it describes learning as fitting newly acquired language into the systems of a language we already possess. Consequently we change, expand, deepen and reconstruct the systems. These are the reasons for us sometimes knowing things without practicing them extensively first. Lightbown and Spada (1993: 25) explain that unexpected periods of considerable improvement or decline in a learner's foreign language development are the consequences of the processes in these systems.

The understanding of the language systems as opposed to individual grammar points and the creative, meaningful use of language were also advocated by Omaggio Hadley (1993: 43-68). The goal of a learner is to become competent in managing new linguistic situations and also to be able to incorporate newly acquired knowledge into his/her existing systems. Professors should try to simulate new situations, teaching the learners to activate and reconstruct their systems and consequently cope with new linguistic situations.

\subsubsection{The Creative Construction Theory of 5 Hypotheses}

In his book, Krashen (1982: 10) highlightes the distinction between second language learning and second language acquisition and offered four hypotheses on learning and acquiring a second language. In his work The Principles and Practice in Second Language Acquisition he offers an explanation and evidential support for his theory.

\subsubsection{The First Hypothesis: The Distinction between Learning and Acquiring}

Krashen (ibid.: 10) argues that the distinction between the process of learning and the process of acquiring a language has been one of the most important suppositions when it comes to second language learning theories.

Learners having acquired rather than learned language structures feel the difference between the two types of knowledge. As they are not conscious of the rules for the structures they acquired, they often say that the structure "felt" or "sounded" correct or wrong.

Learning as opposed to acquiring is then the conscious knowledge one possesses of a language: knowing, thinking and talking about rules in grammar, pronunciation, word formation, etc.

\subsubsection{The Second Hypothesis: The Natural Order}

Krashen (1982: 14) observes that the following theory should encourage educators to reject grammatical sequencing in teaching when their goal is acquisition of a language. He argues that a natural order of acquiring a language exists, meaning there are certain structures that have been proved to be acquired earlier with foreign language speakers than others, namely the ending/ing/in the progressive tense, the plural ending /s/ and the verb 'to be'.

\subsubsection{The Third Hypothesis of the Monitor Model}

The monitor hypothesis elaborates and supports the value of the distinction between learning and acquiring a language. Krashen (ibid.: 15) explains that the processes work both in their own specific ways. He claims that learning has the 
function of monitoring the acquired language before or after we produce utterances (this shows in self-correction).

Bearing individual differences in mind, Krashen (ibid.: 19) differentiates three types of monitor users: monitor over-users, under-users and optimal users.

\subsubsection{The Fourth Hypothesis of Input}

According to Krashen (ibid.: 20), and presuming the Monitor hypothesis is right, a question of how we acquire languages or rather how we move ahead from one stage to another in the development of a language is especially important for the pedagogues and educators around the world. Krashen (ibid.: 21 ) says that "a necessary (but not sufficient) condition to move from stage $i$ to stage $i+1$ is that the acquirer understands input that contains $i+1$ where "understand" means that the acquirer is focused on the meaning and not the form of a message." This simply means that for the learners to progress, they need the input they understand (i) and also some of the input which is just above their level of understanding $(i+1)$. To construct a meaning of a more demanding utterance or text, the learners need context.

Another concept in favour of this hypothesis is, according to Krashen (1982: 26), the idea of a silent period, which is an almost forbidden process with students in formal classes. Not having been allowed to experience the "silent period", students resort to their mother tongue grammar rules - this is what some term transfer. Students using these rules in a foreign language may seem to function better in practical situations, but in the long run, this kind of learning brings many disadvantages, such as errors and less progress. Krashen (1982: 26) argues that "the speaking ability emerges on its own after enough competence has been developed by listening and understanding," when the silent period, during which the learner is receiving input, is allowed to occur.

\subsubsection{The Fifth Hypothesis: The Affective Factor}

Theoreticians have come a long way by establishing that humans are beings who learn by thinking and not by forming habits. Some questions have nevertheless been left unanswered. Why do some people acquire language faster and more substantially than others? How does the personality of a learner influence his/her process of acquiring? The idea of the "affective filter" was introduced by Dulay and Burt (1977) and expanded by Krashen (1982). What supporters of the affective factor theory argue is that humans are emotional beings and that this needs to be accounted for in learning and teaching a language. Hutchinson and Waters (1987: 47) cite Stevick (1976) when they claim that "learning, particularly the learning of a language, is an emotional experience [.]"

To set the process of learning in motion the student needs to have the desire to learn; the nature of thinking depends on the positive or negative emotions one has towards learning the subject matter. In ELT these feelings toward learning are termed motivation.

Krashen (1982: 31) argues that while input still remains the most important variable in learning, it is the affective filter with its 3 categories, namely motivation, self-confidence and anxiety of learners that either helps or obstructs the learners' process of acquiring a language. 


\subsection{Approaches and Methods to Second Language Teaching and Learning}

Krashen and Terrell (1983: 8) state that before the 1600s, people learned languages solely for being able to communicate while trading or negotiating in the market or at sea. This method of acquiring languages was called the direct method and is considered to be the traditional method. This does not mean that there was no concern with grammar at that time; on the contrary, the Greeks and Romans were famous for their grammarians' accomplishments. There are many grey areas as to how the direct method faded away in the second language learning sphere and how the more formal approach to learning languages became so popular.

According to the authors (ibid.), sometime in the $16^{\text {th }}$ century, it became logical for people learning a language to translate statements into their mother tongue - but for that they needed the knowledge of grammar. Grammar-based approaches became ubiquitous around all of Europe. These approaches are still present today in numerous classrooms over the world. The authors, however, note that even though some teachers and researchers stress the importance of grammar, it is still widely assumed that the direct approach is a more natural one when learning a language.

\subsubsection{Direct Methods}

Krashen and Terrell (1983:10) refer to direct methods as involving the use of language in situations of communicative nature while at the same time thinking in the foreign language and not the mother tongue. Grammar in the direct approach is not to be studied deductively - students are supposed to discover the rules by examining texts with a problem-solving approach. A few direct methods have been developed over the course of the last decades: the natural method, the psychological method, the series method, and the phonetic method.

\subsubsection{The Grammar-based Methods}

As a reaction to the direct methods the grammar-based methods such as the reading method, the audio-lingual method (according to Krashen and Terrell (1983:15) it is merely a version of the grammar translation method focussing on the oral skills), the grammar translation method, and the silent way, instruct learners to study the grammatical aspects of a language.

\subsubsection{The Communicative Approaches}

The main purpose of learning a language, i.e. communication, is many times ignored in the way it is taught. Shortcuts and various methods of fast progress in a language have been proposed, because it was wrongly assumed that the knowledge of a language is acquired more quickly when one consciously learns the grammar rules. The authors stress the fact that there might be only a few students who can achieve success (the ability to communicate) in language learning through any of the grammar-based methods.

These are the communicative methods according to Krashen and Terrell: total physical response, suggestopedia, community language learning and the natural approach. 


\subsection{Conclusion of the theoretical part}

There are numerous theories on learning that have been linked to language learning practice, which have not been mentioned in the above overview, such as the multiple intelligences theory, the neurolingustic programming theory or the competencybased education.

The goal of the theoretical part was to briefly describe a few principal characteristics of the main second and foreign language learning and teaching theories and approaches and to list some of the corresponding methods. What the theoretical part aimed to do as well was to portray the constant search of the 'right' method in the field of language teaching over the course of history and to highlight the eventual break of the method concept towards the end of the $20^{\text {th }}$ century. Additionally, the theoretical part is an imperative predisposition for the analysis of the current state of expertise in Slovene private language schools.

\section{EMPIRICAL PART}

\subsection{Methodology}

\subsubsection{Criteria for Selecting Language Schools}

The interviews were conducted with the language schools' managers or their heads of education. I have examined fifteen randomly chosen private language schools or centres from all over Slovenia. This type of selection was made according to the goals of the research. I have tried to discover what education and experience do people running private language schools have, how they convince customers to enrol and whether they deliberately opt for one method or approach. No other particular variable or criterion, such as profit, number of customers, place of activity, or age of the company would be appropriate. By choosing one of these criteria I would automatically reduce the variety of results, and consequently fail to reach the goals of the research.

I am most grateful to all the managers and heads of education of Slovene private language schools who have taken their time to share their experience and knowledge with me.

\subsubsection{Conduct of Interviews}

The fifteen selected schools have been contacted first via telephone and later email to arrange a date of the interview and to preview the questions to be asked in the interview. The choice of a face-to-face interview, an interview via the telephone, or e-mail has been offered to the secretaries to pass on to their managers or to the managers directly.

Three managers (that is $20 \%$ ) decided for an interview in person and others (that is $80 \%$ ) for an interview via the telephone $(75 \%)$ or e-mail $(25 \%)$. The inperson interviews were recorded when allowed (permission was given in all cases) to avoid possible misunderstandings in the analyses. Notes were also taken. 


\subsubsection{Research Questions and Hypotheses}

Research questions presented in the introduction have served as a guide when putting together a questionnaire for the managers and when forming hypotheses. I have set the hypotheses according to my experience and assumptions. Some have proven to be true, others not. The hypotheses are:

1. Managers/heads of education of Slovene private language schools are qualified language teachers. In the case of them being professionals whose area of expertise is non-linguistic, they employ a language teacher as an assistant or advisor.

2. According to their experience and theoretical knowledge, managers choose a particular method or approach the teachers will apply in classes.

3. The arguments in the Why-Choose-Us section on the website or leaflet include or even explain the theory/method/approach applied in the language school.

4. If a school has not decided for a single method, the list of strengths on its website comprises of popular vague statements, such as: small groups, personal approach, quality, adaptability, accessibility, etc.

5. Teachers need to follow the chosen method or approach of the school but are encouraged to apply techniques according to their own preferences and experience.

6. The processes of teachers' self-evaluation and the evaluation of the company's work often take place with observations, meetings, and surveys among clients (once a month).

7. In order to be employed in a private language school one must be a language teacher with some experience in LT.

8. Teacher trainees receive a lot of guidance and professional support, such as seminars, educations programs, observations, demo classes.

The hypotheses have been verified through interviews. However, what needs to be taken into consideration when reviewing the results as well as the analysis is that the research was not meant to be an examination of the actual work done by the teachers in the private language schools. The survey is by no means an accounts of the actual situations in the classrooms, since no observations were made. The interviews have been conducted with the schools' managers solely to establish the validity of the above hypotheses.

\subsubsection{Statistical Analysis}

The data presented includes the so-called 'cleansed' transcripts, meaning that the answers were written in note form, without interjections, and they are not quoted verbatim. Although the interview served as a hypothesis-testing interview, it allowed for unexpected answers and new ideas, which are included in the Results and Discussion chapter.

\subsection{Results and Discussion}

It is difficult to draw conclusions and generalisations, even though sometimes answers may seem alike. For this very reason, the statistical methods used in this section include the quantitative analysis method, where similar answers have been counted to either confirm or reject a hypothesis, and the qualitative method, where ideas that have sprung up in the conversation, but are not considered answers to the pre-prepared questions, have been examined too. 
There are no dependent and independent variables. The aim of the research has been to briefly examine the level of professionalism in Slovene private schools and not to experiment with variables.

\section{Hypothesis 1}

Managers/heads of education of Slovene private language schools are qualified language teachers. In the case of them being professionals whose area of expertise is non-linguistic, they employ a language teacher as an assistant or advisor.

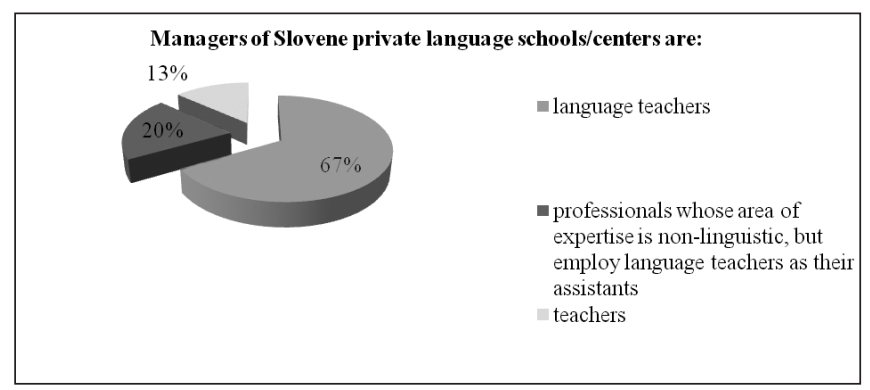

Table 1: Hypothesis 1

The hypothesis has been confirmed; most managers of Slovene private schools are in fact language teachers. If not, they employ somebody who is.

\section{Hypothesis 2}

According to their experience and theoretical knowledge, managers choose a particular method or approach the teachers will apply in classes.

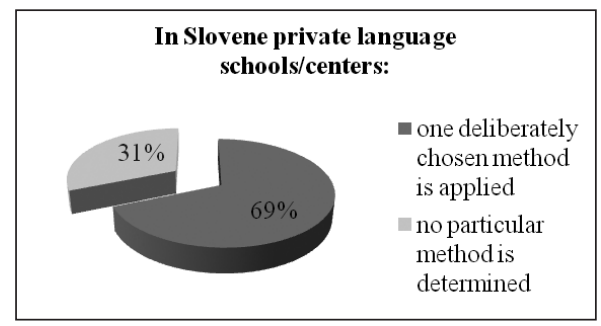

Table 2: Hypothesis 2

The hypothesis has been proven to be true. Research has shown that the majority of the schools apply the communicative method. The managers who do not adhere to a particular method talk about their teachers adopting a "method of life", or a "method of variability", even a "method of practicality", explaining they adapt the methods to their customers and strive to teach language which is used in everyday life in a way that is similar to real life situations. 


\section{Hypothesis 3}

The arguments in the Why-Choose-Us section on the website or leaflet include or even explain the theory/method/approach applied in the language school.

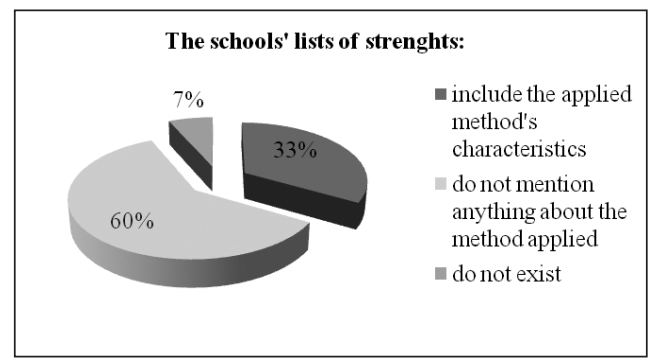

Table 3: Hypothesis 3

Lists of promises or achievements are to be found on most of the schools' websites. Some briefly mention their way of teaching as an advantage. Those, however, which follow a less-common method elaborately explain and give arguments for their way of teaching. Some schools decide not to post their strengths online.

\section{Hypothesis 4}

If a school has not decided for a single method, the list of strengths on its website comprises of popular vague statements, such as: small groups, personal approach, quality, adaptability, accessibility, etc.

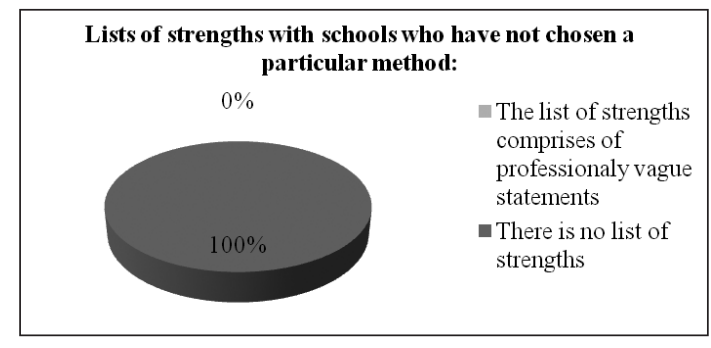

Table 4: Hypothesis 4

To my surprise, the schools which have opted against choosing a particular method do not list their strengths.

\section{Hypothesis 5}

Teachers need to follow the chosen method or approach of the school but are encouraged to apply techniques according to their own preferences and experience. (Q 8) 


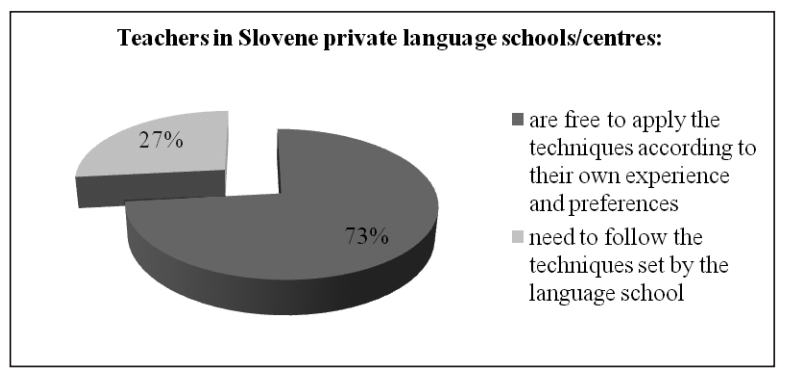

Table 5: Hypothesis 5

Most schools which either have no set method or follow the communicative approach let their teachers choose the techniques according to their own experience of what is effective. Nevertheless, they need to remain within the framework of the schools' principles and values (which are mostly: communication before grammar, practicality, etc.).

Other language centres and schools, who have adopted an uncommon method of teaching, leave no room for autonomy: teachers attend seminars to learn the concepts of the method as well as the practical operative strategies, known as techniques.

\section{Hypothesis 6}

The processes of teachers' self-evaluation and the evaluation of the company's work often take place with observations, meetings and surveys among clients (once a month).

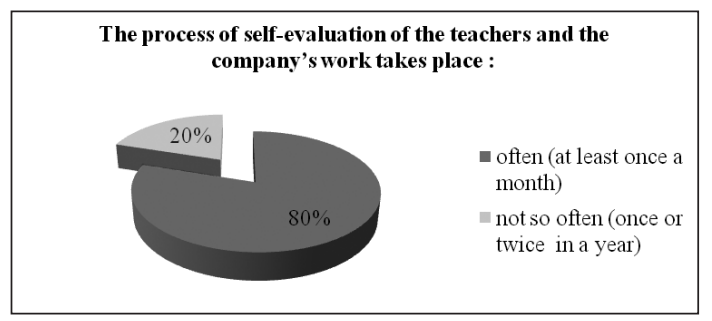

Table 6: Hypothesis 6

Most schools pay much attention to evaluating the work of their teachers and also spend a great amount of time and effort on prompting feedback from their customers. Conversely, some schools decide that a teacher will be given a group to teach and later be assessed also according to the learners' feedback.

\section{Hypothesis 7}

In order to be employed in a private language school one must be a language teacher with some experience in LT. 


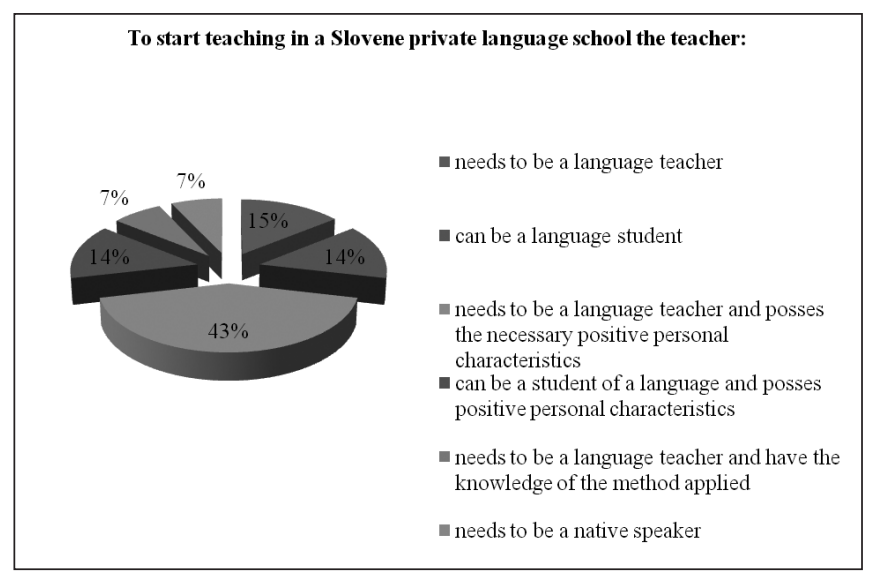

Table 7: Hypothesis 7

Almost all of the managers talked about the importance of teachers positive personal characteristics. They have listed the following personality traits as necessary for teachers to have: joyful, light-hearted, energetic, respectful, responsible, and talkative. Some believe it is essential for the teacher to have a feel for people, so he/she can adapt and so the learners feel secure around them. Many also seek professionals who are passionate about teaching. Experience has rarely been mentioned as being a criterion for employment. Numerous schools, however, claim they would not employ somebody who has not finished their studies. The hypothesis has partially been confirmed.

\section{Hypothesis 8}

Teacher trainees receive a lot of guidance and professional support, such as seminars, educations programs, observations, demo classes.

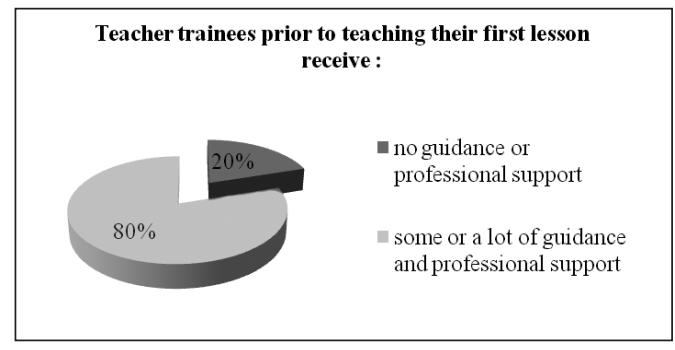

Table 8: Hypothesis 8

Schools with no guidance or support for the teacher trainees in the form of demo classes, observation classes or seminars are rare. Many offer various forms of education, and others even have obligatory seminars or education programs. 


\subsection{Conclusion}

I have answered the questions set out at the beginning of the research concerning the level of professionalism in Slovene private language schools. The theoretical knowledge gained while constructing the short overview of theories, approaches, and methods has been vital for the conduct of the interviews and the analysis.

Some interviewees answered only my questions, while others discussed numerous pedagogical topics after the formal part of the interviews had been over. I have not included those comments in the analysis, but rather took the opportunity to converse with them casually.

The continuation of this study would most probably include the analysis of methods and approaches applied in schools, only this time national schools would be the subject of research. Some managers I have met are also mothers and the methods applied in national schools sprung up in conversations.

I have considered the hypotheses to be proven when at least $50 \%$ of the answers were in favour of the hypothesis. All but one have been confirmed. I hoped my hypotheses would not turn out to be naive statements about what the market of language course offers should be. The hesitations and dilemmas of managers or heads of education when asked which method is applied in their schools prove that even though the hypotheses have been confirmed, there are about $30 \%$ of Slovene private language schools on average which do not offer language courses learners would deserve.

The possibility of some untruthful answers should be taken into account due to the research being carried out through conversations and not scientific observations. However, for the purposes of this research the abovementioned limitations do not influence the results. If I had wished to inspect and investigate whether the private schools are truly applying the methods advertised, then another method of research would have been more appropriate.

Only hypothesis 4 has been rejected. Schools without a particular adopted method or approach do not list their strengths; what is more, they refrain from advertising lists of popular, usually vague marketing phrases, such as small groups, personal approach, etc.

On the other hand, the schools with a certain method explicitly advocated on their website enumerate characteristics, which seem to be forever popular no matter how over-used and vague they may have become: accessibility, modern approaches, small groups, experienced teachers, etc.

Reassuring are the facts that most Slovene private schools are managed by language teachers, and that they offer a lot of guidance and support to teacher trainees.

Equally comforting are the findings that a teacher is fairly independent when techniques of teaching are in question.

Slovene private language schools maintain the level of quality service by constantly self-evaluating, educating, and assessing teachers as well as prompting feedback from their customers.

As far as the applied methods are concerned, the situation is rather disappointing, although this fact is not immediately seen in the percentage tables. 
Many of the managers answered with a question in reply to "Is there a particular method or approach you are keen on?". They wondered which methods even exist, claiming they had forgotten the theoretical guidelines. Once the methods were suggested, most of them decided for one of the latest approaches, i.e. the communicative approach.

One of the managers explained that due to the variety of people, a variety of methods should be applied. She believes the eclectic approach is the perfect one, claiming she is aware of the decades-long search for the one method that would benefit all learners equally. She says a teacher needs to posses the skill of recognising what method or approach would bring joy and success to an individual learner. She claims teachers in her school are such teachers.

Some centres in Slovenia advertise a holistic approach to learning a language and more schools are starting to offer this kind of courses. The popularity of and confidence in learning in the alpha stage has increased as well.

\subsection{Applicability and relevance of results}

Firstly, the results gained mostly highlight how little attention teachers and managers pay to theoretical knowledge of second language teaching methodology. This is beneficial to each teacher as it encourages stricter self-evaluation. Even though some teachers with little theoretical knowledge educate wonderfully and their students are successful, they still need to evaluate their work according to international findings and theories in order to gain a more professional insight into their way of teaching. An in-depth analysis of one's work brings about realizations and further research which are necessary for personal and professional growth, not to mention the dynamics and the conduct of lessons taught.

And secondly, being aware of the search of "the perfect" method during the last decades, teachers are more capable of critically evaluating whatever is presented and sold to them as materials, coursebooks or teacher-training programs of high quality.

Last, but certainly not the least important findings of the research are the private language schools' criteria for hiring a teacher. In order to be employed in a language school a teacher needs to be a positive and a patient person. Although native speakers remain extremely popular, managers have ensured me that suitable education is an absolute prerequisite.

\section{BIBLIOGRAPHY}

Celce-Murcia, M. (2001) Teaching English as a Second or Foreign Language. Boston, Mass.: Heine \& Heinle.

COLEMAN, A. (2000) The Teaching of Modern Foreign Languages in the United States: a report prepared for the Modern Foreign Language Study. New York: The Macmillan Company, 1929. Cook, G. "Is Direct Method in our Madness?” IN, IATEFL Slovenia 18, 18-19. 
DULAY, H./ M. BURT (1977) Remarks on creativity in language acquisition. In M. Burt, H. Dulay and M. Finnochiaro (Eds.) Viewpoints of English as a Second Language. New York: Regents Pub. Co, 95-126

HUBBARD, P./H. JONES/B. THORNTON/ R. WHEELER (1983) A Training Course for TEFL. Oxford: OUP.

HUTCHINSON, T./ WATERS A. (1987) English for Specific Purposes: a learning-centred approach. Cambridge: Cambridge University Press.

LIGHTBOWN, P.M./SPADA, N. (1993) How Languages Are Learned. Oxford: Oxford University Press.

KRASHEN, S.D. (1982) Principles and Practice in Second Language Acquisition. Oxford: Pergamon Press.

OMAGGIO HADLEY, A. (1993) Teaching Language in Context. Boston, Mass.: Heinle and Heinle Publishers.

RICHARDS, J.C./ T.S. RODGERS (2001) Approaches and Methods in Language Teaching. Cambridge: Cambridge University Press.

SKELA, J. (2005) "The communicative approach to foreign language teaching: naturally rational or rationally natural?: a picture history of ELT”. Vestn. - Druš. tuje jez. književ., 39, no. 1/2, 93-111.

\section{INTERNET SOURCES}

Merriam Webster Dictionary Online. 11 July 2011. http://mw1.merriam-webster. com/dictionary/schemata

\section{POVZETEK}

\section{Načela katerih teorij poučevanja tujega jezika se skrivajo $v$ ponudbah jezikovnih te- čajev v Sloveniji?}

Članek pod drobnogled vzame ponudbo jezikovnih tečajev v Sloveniji. Kdo so ljudje, ki vodijo jezikovne šole? Katerim kriterijem morajo zadostiti novi učitelji? Ali se jezik poučuje v skladu z načeli izbrane metode, oziroma ali je bila metoda sploh izbrana? Katere tehnike poučevanja so prisotne $\mathrm{v}$ učilnicah in kdo jih izbira?

Zgodovina odkritij metod poučevanja tujega jezika je bila deležna veliko kritike in skepticizma. Učitelji vsepovsod po svetu so bili zmedeni, saj sta bili popularnost in zaupanje v metodo hitro minljivi. Te okoliščine so se spremenile ob koncu 20. stoletja, ampak ali so posledice tega danes vidne?

$\mathrm{Na}$ tovrstna vprašanja so odgovore ponudili direktorji 15 zasebnih jezikovnih šol v Sloveniji.

Analiza intervjujev je pokazala, da večino šol v Sloveniji vodijo jezikoslovci ali pa ekonomisti, ki zaposlijo učitelja za upravljanje tečajev. Večina šol se odloči za eno metodo poučevanja. Učiteljem, ki prvič poučujejo v neki šoli, vodstvo nudi veliko strokovne podpore in nasvetov. Večina učiteljev lahko izbere svoje tehnike poučevanja, če le sledijo začrtanim smernicam šole. Pogoji za zaposlitev so različni: nekateri direktorji zahtevajo diplomiranega profesorja z izkušnjami, spet drugim je dovolj, če je učitelj domači govorec. Številni poudarjajo, da učitelje izbirajo tudi na podlagi osebnostnih lastnosti, in veliko direktorjev 
bi zaposlilo le veselega in energičnega učitelja. Delo učiteljev in napredek tečajnikov šole se pogosto ocenjuje sproti.

Ključne besede: teorije o učenju maternega jezika, metodologija poučevanja drugega/ tujega jezika, zgodovinski pregled poučevanja jezikov, slovenske zasebne jezikovne šole/ centri

\section{ABSTRACT}

\section{Which Second Language Learning Theories Underlie Language Courses Offered by Slovene Private Language Schools}

The article deals with language courses offered by private language schools in Slovenia. It examines who the people in charge of the language schools are, what criteria new teachers have to meet to become an employee of a school, whether the methodology applied (if any) has been carefully chosen, what the teaching techniques are and who chooses them.

Second language method discoveries have been subjected to perennial criticism and scepticism over the last half of century. Teachers around the globe have been confused by the constant shifts in the popularity of different methods. The article examines the consequences of the abovementioned circumstances.

The 15 interviews conducted with private language schools' managers have generated valuable information on the level of professionalism in this area of business.

The results have shown that most of the randomly chosen schools are managed by language professionals or by economists who employ a linguist for controlling the teaching and learning processes and that the majority of schools does adopt a particular approach or method of teaching. Teacher trainees receive a lot of support and guidance prior to teaching in a school. In most cases, teachers are free to choose techniques of teaching according to their preferences, providing the techniques are not in conflict with the general schools' principles. The criteria for employment vary considerably. Nearly all managers would employ a professional language teacher with experience only, but others demand that the teacher be a native speaker regardless of his/her education. Several stress the importance of personal characteristics and would consider employing only light-hearted and energetic teachers. Teachers' work and students' progress are often evaluated.

Key words: first language acquisition theories, methodology of second or foreign language teaching and learning, a historical overview of language teaching, a break with the method concept, Slovene private language school and/or centres 